\title{
Rational hope, possibility, and divine action Andrew Chignell
}

The whole domain of the supernatural is thus removed from the region of belief into that of simple hope, and in that, for anything we can see, it is likely always to remain.

- J. S. Mill, Theism

Voltaire said that Heaven has given us two things as a counterweight against the many burdens of life: hope and sleep. He might well have added laughter...

- Kant, Critique of Judgment 5:334

\section{Kant's third question}

One of the arguments for which Kant is best known (or most notorious) is the so-called "moral proof" of the existence of God, freedom, and the immortal soul. Versions of the proof can be found in each of the Critiques, in various lectures, and in Religion within the Boundaries of Mere Reason. "Proof" has to be taken loosely here, since the attitude licensed by moral considerations, for Kant, is not knowledge but rather Belief (Glaube). ' Still, loose talk of "proof" is appropriate insofar as the argument is supposed to motivate not mere Belief or faith but rather "rational Belief (Vernunftglaube)" - i.e. assent that is justified in a non-epistemic way for finite practical agents. Kant is hardly advocating an irrationalist leap into dogmatic or mystical fancy.

Because the moral proof is so well-known, and because at least two of its objects are broadly religious - God and the immortal soul - it comes as a surprise when he indicates in a 1793 letter to the theologian C. F. Stäudlin that such Belief is not the main focus of the philosophy of religion. It's really moral philosophy that deals with Belief; philosophy of religion, in contrast,

My thanks to Eric Watkins, Karl Ameriks, an anonymous reviewer for Cambridge University Press, and audiences at the APA and the Humboldt Universität zu Berlin for helpful feedback on earlier drafts.

' Glaube is an ambiguous German term that is typically translated as either "belief" or "faith." I prefer to avoid the latter term, since not all Glaube has to do with religious doctrine. Here I'll use capitalized "Belief" in order to distinguish it from contemporary notions of "belief." See Andrew Chignell, "Belief in Kant," Philosophical Review II6 (2007), pp. 323-60, for more on Kant's general notion of "Belief." 
is concerned with the attitude of hope (Hoffnung). It's even more surprising that Kant gives hope, rather than Belief, pride of place in the list of questions that motivate his entire critical philosophy:

all interest of my reason (the speculative as well as the practical) is united in the following three questions:

I. What can I know?

2. What should I do?

3. What may I hope? (A806/B833)

The third question somehow unites the first two: it is "simultaneously practical and theoretical" - it "concerns happiness" and "finally comes down to the inference that something is ... because something ought to happen." In this way "the practical leads like a clue to a reply to the theoretical question and, in its highest form, the speculative question" (A805-6/B833-4, original emphasis). ${ }^{3}$

Commentators typically neglect the distinct nature and role of hope in Kant's system, and simply lump it together with the sort of Belief that arises from the moral proof. ${ }^{4}$ Indeed, Kant himself is not entirely innocent of the conflation..$^{5}$ I want to suggest below, however, that, from a conceptual as well as a textual point of view, hope should be regarded as a different kind of attitude. It is an attitude that we can rationally adopt toward some of the doctrines that are not able to be proved from within the bounds of mere reason - either theoretical or practical. This does not mean that hope is unconstrained; there are rational limits, as we shall see. In fact one of my central claims here is that a

${ }^{2}$ See the letter to C. F. Stäudlin of May 4, ${ }^{7} 793$ (Brief II:429), as well as the introduction to the Jäsche Logic of 1800 (9:25).

${ }^{3}$ In the letter to Stäudlin and the introduction to Logic, Kant adds a fourth question to the list - namely, "What is the human being? (Was ist der Mensch?)" (L 9:25).

${ }^{4}$ See, e.g., Hermann Cohen, Reason and Hope: Selections from the Writings of Hermann Cohen, ed. and trans. Eva Jospe (New York: W. W. Norton, 197I); Onora O’Neill, “Kant on Reason and Religion” (Tanner Lectures on Human Values, 1996); Philip Rossi, "Kant's Doctrine of Hope: Reason's Interest and the Things of Faith," New Scholasticism 56 (1982), pp. 228-38; Christopher McCammon, "Overcoming Deism: Hope Incarnate in Kant's Rational Religion," in Chris L. Firestone and Stephen Palmquist (eds.), Kant and the New Philosophy of Religion (Bloomington: Indiana University Press, 2006), pp. 79-89; Katrin Flikschuh, "Hope as Prudence: Practical Faith in Kant's Political Thinking," International Yearbook of German Idealism 7 (2009), pp. 95-II7. Hope comes up more often in Kant's later writings, and some readers may conclude that Kant was weakening his earlier and very strong claims about the necessity of firm rational Belief - perhaps, as Heine would have it, in response to his own fading religious commitments. In fact, though, the question about hope is already there in the $178 \mathrm{I}$ A-edition. It's just that, as Kant tells Stäudlin in the I793 letter, he hadn't had a chance to discuss religion in detail prior to writing Religion.

5 See the top of $R$ 6:62 where the ability to "hope to become pleasing to God (and thereby blessed)" seems to be equated with someone's being "entitled to consider himself not an unworthy object of divine pleasure." But being able to hope to become $x$ is clearly a weaker state than that of being entitled to consider oneself $x$. 
crucial difference between knowledge, rational Belief, and rational hope is that they are governed by different modal constraints; section II discusses those constraints and the kind of modality involved. In section III, I return to Religion and offer what I take to be Kant's account of the main objects of rational hope in that text - namely, "alleged outer experiences (miracles)"; a "supposed inner experience (effect of grace)"; and a future collective experience (the construction of a truly ethical society) $(R 6: 53){ }^{6}$

\section{The Structure of rational hope}

\section{I Modal constraints}

What sorts of entities or states can we rationally hope for, given our ethical situation and psychological make-up? We have seen that Kant thinks something about "the practical" is supposed to lead "like a clue" to a commitment regarding what is - i.e. regarding a theoretical entity or state. This doesn't mean that practical considerations somehow provide theoretical grounds (i.e. empirical or a-priori reasons) for these doctrines. Rather, the talk of "theoretical" or "speculative" is just Kant's way of referring to propositions regarding what exists - that is, things or states that we include in our ontology, broadly speaking. In the case of hope as well as Belief, the grounds for assent regarding "theoretical" entities will be almost wholly practical."

${ }^{6}$ Kant was by no means the first among Western religious thinkers to claim that hope is worth discussing in a religious context. There is a Pauline precedent for conceiving hope along with faith as near the top of the list of theological virtues, though not quite as important as love. Augustine has a long discussion of hope in The Enchiridion: Faith, Hope, and Love, as well as some comments on the virtue of hope in his tractates on the First Letter of John. Peter Lombard dedicated some of his Sentences to the concept of hope, and as a result of this nearly everyone in the later medieval tradition remarked on it in their Sentences-commentaries. Bonaventure is a prime example, though his account of hope is unusual in that he construes it as a kind of meta-virtue: the sustained affective commitment that helps us keep our faith constant and our loves properly ordered. See Rachel Lu, "Natural and Supernatural Virtue in St. Bonaventure," dissertation submitted to Cornell University, 20I2. In most of these thinkers, however, remarks about hope are sandwiched between much longer discussions of faith and love. As far as I know, no one prior to Kant suggested that hope is the central attitude in religion, and thus the central topic of the philosophy of religion. After Kant, in contrast, there have been further efforts in that direction, typically by authors who are themselves deeply influenced by Kant - Ernst Block, Das Prinzip Hoffnung (Frankfurt am Main: Suhrkamp, 1959); Jürgen Moltmann, Theologie der Hoffnung: Untersuchungen zur Begründung und zu den Konsequenzen einer Christlichen Eschatologie, 3 rd edn. (Munich: C. Kaiser, 1965); James L. Muyskens, The Sufficiency of Hope: Conceptual Foundations of Religion (Philadelphia: Temple University Press, 1979).

7 I say "almost" because there is some talk of "theoretical" grounds for Belief in Kant's writings as well. See Chignell, "Belief in Kant," and Lawrence Pasternack, "Kant's 'Doctrinal Belief in God," in Oliver Thorndike (ed.), Rethinking Kant. Vol. III (Newcastle upon Tyne: Cambridge Scholars Press, 20II), pp. 200-I8, for discussion of this interesting hybrid attitude. 
By comparison with our ordinary concept of "belief" or "knowledge," there is very little discussion of hope in recent philosophical literature. Indeed, one philosopher - J. P. Day ${ }^{8}-$ begins his 1969 paper on the topic with the claim that philosophers have completely abandoned hope. That's not quite fair there were a few authors before Day (such as Wheatley, Bloch, and Downie) ${ }^{9}$ who had kept hope alive philosophically. If there was a consensus analysis amongst the more analytical mid-century authors, it was something like this:

$S$ hopes that $p$ if and only if

(HI) $S$ desires that $p$, and

(H2) $S$ believes that $p$ is possible.

Phillip Pettit ${ }^{\mathrm{IO}}$ refers to this as the "lowest common denominator" conception of hope - first, because it is common in a lot of those earlier discussions, and second because $\left(\mathrm{H}_{\mathrm{I}}\right)$ and $\left(\mathrm{H}_{2}\right)$ are shared by more robust analyses, including his own. Luc Bovens, Ariel Meirav, and Adrienne Martin, likewise take this to be the "orthodox account" (Martin's term) before going on to offer refinements and additions. ${ }^{\text {II }}$

(HI) could be made more precise, but the idea behind it seems uncontroversial: if I hope that $p$ is true, then I have some sort of desire or proattitude toward $p$ 's truth. But what about $\left(\mathrm{H}_{2}\right)$ ? Clearly $p$ can describe an event that has not yet occurred - I hope that it will be sunny in Ithaca (and believe that this is at least possible). But the relevant $p$ can also describe events that have already occurred but whose details are unavailable to me. If I wasn't there and haven't heard any news about the matter, I can hope that (i.e. desire and believe possible that) it wasn't cloudy yesterday, even though the facts of the case have been settled. Once I learn that Ithaca has been experiencing one of its characteristic month-long gray spells, my hope disappears.

But even with this in mind, $\left(\mathrm{H}_{2}\right)$ as stated is too strong: for surely someone can hope for $p$ even if he or she has no actual beliefs at all occurrent or dispositional - about the modal status of $p$. Consider, then, the somewhat weaker

8 John P. Day, "Hope," American Philosophical Quarterly 6 (1969), pp. 89-102.

9 J. Wheatley, "Wishing and Hoping," Analysis I8 (1958), pp. I2I-3I; Bloch, Das Prinzip Hoffnung; Robin S. Downie, "Hope," Philosophy and Phenomenological Research 24 (1963), pp. 248-5I.

Io Philip Pettit, "Hope and its Place in Mind," Annals of the American Academy of Political and Social Science 592 (2004), pp. 152-65.

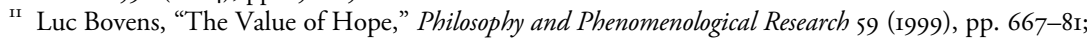
Pettit, "Hope and its Place in Mind"; Ariel Meirav, "The Nature of Hope," Ratio 22 ( 2009), pp. 216-33; Adrienne M. Martin, "Hopes and Dreams," Philosophy and Phenomenological Research 83 (201I), pp. I48-73, and How We Hope (Princeton University Press, 2013). 
(H2rev) $S$ is in a position to believe that $p$ is possible.

This is an improvement, although "in a position" clauses are notoriously tricky. For present purposes, we can simply take it to mean that a certain counterfactual is true - namely, that $S$ would believe that $p$ is possible if he were to form a belief on the matter.

In a different context it would be worth embarking on a series of thoughtexperiments designed to specify further, more complicated, and jointly sufficient conditions. Here, however, I'll simply work with (HI) and (H2rev), and take them to state significant necessary conditions. In other words, I'll take desiring something and being in a position to believe that it is possible to be two of the main components of paradigmatic hope, even if they are not the whole story.

Note that the question Kant asks is not about what we do hope or can hope, but about what we may hope - the German here is "Was darf ich hoffen?" "May" connotes a concern about rational permissibility, a concern whose source, presumably, is the recognition that the desire in (HI) or the belief in $\left(\mathrm{H}_{2} \mathrm{rev}\right)$ might be irrational, and that irrationality might transfer to the hope as well. If I irrationally believe that it is possible to find water that is not $\mathrm{H}_{2} \mathrm{O}$, and for some reason want to do so, then it looks like the irrationality of the modal belief will infect my hope as well, even if the desire is well founded.

This suggests that, even if the conjunction of $\left(\mathrm{HI}_{\mathrm{I}}\right)$ and $\left(\mathrm{H}_{2} \mathrm{rev}\right)$ provide an account of two significant necessary conditions on hope simpliciter, we need something more if we are to capture Kant's talk of the hopes that we may have. For present purposes, I propose to set aside questions about the rationality of desire and focus on the second condition. (H2rev) is satisfied when a subject is in a position to have a modal belief about the object of hope, and so the addition here will presumably relate to the rationality of that belief. We can capture both of these ideas by speaking not of justified belief, but of being justified in believing. The idea, then, would be that

$S$ rationally hopes that $p$ only if

(RHI) $S$ rationally desires that $p$, and

(RH2) $S$ is justified in believing that $p$ is possible.

To go further with respect to the second condition, we clearly need to grasp what sort of possibility Kant is invoking. ${ }^{\text {I2 }}$ This will require a quick detour through the chapter in the first Critique that takes modality as its focus - the "Postulates of Empirical Thinking."

I2 We would also need an account of what it is to be justified in believing some proposition. In order to avoid such a Herculean assignment here, perhaps we can simply agree on a rough-and-ready characterization: $S$ must possess whatever is required for the relevant belief, if she forms it, to be justified. 


\subsection{The possibilities of hope}

\section{Empirical possibility}

Does the modal condition on hope involve what Kant sometimes refers to in the Critique as "empirical possibility"? This is the modal status enjoyed by events or changes of state that are compatible with preceding states, given the empirical laws. ${ }^{13}$ So is hope rational only when directed toward something that we are justified in taking to be empirically possible in this way?

Such a constraint, it seems to me, would be too weak in one sense, and too strong in another. Too weak because at least some of the paradigmatic objects of Kantian hope are not entirely empirical - Kant often speaks of hope for a "moral world," and such a world presumably involves our intelligible, ethical characters. This kind of moral state may in some minimal sense be "compatible" with empirical laws and preceding events, since, qua moral state, it is not really part of the empirical nexus at all. But that kind of compatibility is not what is meant when people (Kant included) articulate modal conditions in terms of empirical possibility. In other words, we don't normally regard something as empirically possible just because it is not an empirical object or state at all (e.g. an abstract object) and so ipso facto fails to violate (or follow from) empirical laws. Rather, we ascribe empirical possibility to something that is itself an empirical object or event, one that, at the very least, positively coheres with the conjunction of the empirical laws and the description of all previous events.

There is another sense, however, in which construing the constraint in $\left(\mathrm{RH}_{2}\right)$ as involving empirical possibility is too strong. For the "moral world" does have an empirical component or upshot - Kant famously thinks that the highest good involves not just virtue (i.e. worthiness to be happy), but also genuine "happiness in the world proportionate to the worthiness to be happy" ( $R$ 6:8n). Such happiness - for sensing, feeling creatures like us will be partly empirical $(R 6: 6-7 \mathrm{n})$. And yet, for all we know, such happiness may not be in keeping with the empirical laws of the actual world and thus may be empirically impossible. And there might be other empirical anomalies for which one can, in the right context, reasonably hope (see section III below). If this is right, then a reading of the modal constraint in ( $\left.\mathrm{RH}_{2}\right)$ as empirical fails in at least two different ways.

${ }^{13}$ See A22off./B268ff., as well as Andrew Chignell and Nicholas Stang, "Postulate des empirischen Denkens," in G. Mohr, J. Stolzenberg, and M. Willaschek (eds.), Kant-Lexicon (Berlin: Walter de Gruyter, 20I4), n.p. 


\section{Formal possibility}

What other kinds of possibility are available? In the first of the three Postulates, Kant develops the notion of a more abstract kind of modality that invokes not the actual initial conditions and empirical laws, but rather the general "formal conditions" of our experience, conditions that may well be consistent with non-actual conditions and non-actual laws. He defines it as follows: "That which agrees (übereinkommt) with the formal conditions of experience (according to intuition and concepts), is possible" (A218/ $\mathrm{B} 265)$.Here too there is a question about what "agreement" with the formal conditions of experience requires. Kant's own examples are of little help he cites the following as "mere figments of the brain" that do not agree with the formal conditions of experience: "A substance that is persistently present in space yet without filling it ... or a special fundamental power of the mind to intuit the future ... or, finally, a faculty of our mind to stand in a community of thoughts with other men (no matter how distant they may be)" (A222-23/B270). Although the concepts of such things are logically coherent, Kant admits, the claim that their objects are possible is "totally groundless ... because they cannot be founded on experience and its laws with which we are acquainted (weil sie nicht auf Erfahrung und deren bekannte Gesetze gegründet werden kann)" (A223/B270).

But what does "experience and its laws with which we are acquainted" mean in this context? I've been simply assuming that the formal "laws" here are the a-priori formal laws of experience - specifically, the principles derived from the categories, such as the Causal Principle of the Second Analogy. But the examples Kant cites (telepathy, soothsaying, ghost-like entities) are not - or not obviously - incompatible with such highly general and formal principles. If, on the other hand, "laws" refers to the empirical laws, then Kant would be saying merely that we do not know that these items are compatible with the specific empirical laws of the actual world. But then it is not clear why this would support agnosticism about their formal possibility. Again, Kant defines formal possibility here as compatibility with the formal conditions of experience, and these are supposed to be far less determinate than specific empirical laws and thus compatible with different sets of them. ${ }^{\text {I4 }}$

If we apply this point to the hope issue, formal possibility seems too weak to be a candidate for inclusion in $\left(\mathrm{RH}_{2}\right)$, given that numerous states of the

${ }^{\text {I4 }}$ See Chignell and Stang, "Postulate," for more discussion of this puzzle, and of the Postulates generally. 
intelligible realm - some of which ground the happiness of the virtuous, and some of which don't - are "compatible" with the formal conditions of intuition and category-application. Such a flaccid principle is surely not what's intended by someone trying to provide an informative account of rational hope.

\section{Logical possibility}

What, then, about strict logical possibility? Is the constraint on rational hope in $\left(\mathrm{RH}_{2}\right)$ that its objects must be logically possible, or at least taken by the subject to be so? This is also too weak. It's true that logic prevents me from rationally hoping that $2+2=5$ or that I will meet a married bachelor someday. So a constraint that entails logical possibility is presumably involved. But hope seems equally irrational, fanciful, and false when its object is water that has a chemical constituency other than $\mathrm{H}_{2} \mathrm{O}$, or a zombie with empathetic feelings, or an event without a cause, or (to use Kant's own example in the Postulates) two straight lines that manage, on their own, to enclose a figure (A22O-2I/B268). We need to find something stronger if the condition in $\left(\mathrm{RH}_{2}\right)$ is to limn the contours of the relevant domain.

\section{Real possibility}

What philosophers now call metaphysical possibility offers, I submit, the right joint at which to carve. It may seem anachronistic to import this notion - lost in early analytic philosophy but rehabilitated by Kripke and others at the end of the twentieth century - into a discussion of Kant's philosophy. But in fact Kant develops and uses a modal notion that is quite similar: he calls it "absolute possibility" in the Postulates chapter, and elsewhere simply "real possibility." Absolute (real) possibility "goes beyond all possible empirical use of the understanding" and relates to things and their natures per se - it has to do with what is "possible in all respects" rather than "possible only under conditions that are themselves merely possible" (A232/B284).

The concepts of real possibility and real necessity are found in Kant's thought as early as the I760s, and they play an important role throughout his career. In the critical period, for instance, Kant famously argues that we must not go beyond the domains of empirical and formal possibility and make speculative inferences to first causes, intelligent designers, free wills, world-wholes, and other supersensibles. Why not? At least one of his concerns is that those speculative concepts may contain predicates that are "really repugnant" - either alone or in combination. In other words, the 
objects of these thoughts may be really impossible, for all we know, and thus for epistemic purposes we ought to regard them as mere "figments of the brain, for the possibility of which there would be no indications at all" (A222/B270). ${ }^{\mathrm{IS}}$

Given that Kant clearly employs a notion of real modality throughout his career, we needn't be too concerned about anachronism in the present context. The proposal, then, is that the second condition in the analysis of rational hope should be

(RH2revised) $S$ is justified in believing that $\mathrm{p}$ is really possible.

Many of Kant's explicit references to hope support something very much like this conception. Here is one of the crucial passages in the first Critique:

it is equally necessary to accept in accordance with reason in its theoretical use (eben so nothwendig sei es auch nach der Vernunft, in ihrem theoretischen Gebrauch anzunehmen) that everyone has grounds (Ursache) to hope for happiness in the same measure as he has made himself worthy of it in his conduct, and that the system of morality is therefore inseparably combined with the system of happiness, though only in the idea of pure reason. (A809/B837)

Note the phrase "accept ... that everyone has grounds to hope." Given the practical context of the discussion, it is clear that "acceptance" here is equivalent to Belief (Glaube) in the technical Kantian sense, and indeed Kant often treats these two terms - Annehmung and Glaube - as synonyms. What we are Believing in this practical way, then, is that everyone has (non-epistemic) grounds to hope for happiness in proportion to his or her own virtue.

It is crucial to see that Kant is not encouraging us baldly to accept that there actually is a necessary connection between virtue and happiness. Rather, the most that rational hope requires is that we Believe that such a connection is really possible. Kant says something similar in the third Critique: a "righteous man (like Spinoza)" who seeks to be self-consistent

must accept (annehmen) the existence of a moral author of the world, i.e. the existence of God from a practical point of view, so that he can at least form a concept of the possibility of the final end that is morally prescribed to him; and

is For more discussion of real repugnance, see Andrew Chignell, "Real Repugnance and our Ignorance of Things-in-Themselves: A Lockean Problem in Kant and Hegel," International Yearbook of German Idealism 7 (2009), pp. 135-59; and "Real Repugnance and Belief about Things-in-Themselves: A Problem and Kant's Three Solutions," in James Krueger and Benjamin Bruxvoort Lipscomb (eds.), Kant's Moral Metaphysics: God, Freedom, and Immortality (Berlin/New York: de Gruyter, 20Io), pp. I77-2II. 
he can indeed do this, since [such an idea] is at least not intrinsically contradictory. ( $K U 5: 452-3$, my emphasis)

God's actual existence is accepted as a condition of the real possibility of a moral world, which is something we also positively accept/Believe. In Kant's own view of rational hope, then, it looks like (RH2revised) has to give way to

(RH2Kant) $S$ at least rationally Believes that $p$ is really possible.

The difference between ( $\mathrm{RH}_{2}$ revised) and ( $\mathrm{RH}_{2}$ Kant) is that the former doesn't require the subject to have any positive attitudes at all, while the latter does. For the supersensible objects of hope we're concerned with in religious contexts, the relevant attitude will be Kantian Vernunftglaube based on practical grounds. But the "at least" in ( $\mathrm{RH}_{2} \mathrm{Kant}$ ) is supposed to indicate that different attitudes with different kinds of justification might be appropriate in other contexts.

We have now arrived at two of the most significant necessary conditions on Kantian rational hope:

$S$ rationally hopes that $p$ only if

(RI) $S$ rationally desires that $p$,

( $\mathrm{RH}_{2}$ Kant) $S$ at least rationally Believes that $p$ is really possible.

With this partial analysis as well as a sense of the modal theory in the background, we can now turn directly to Religion in an effort to understand its account of some of the main objects of rational hope.

\section{Rational hope and Kantian religion}

\section{I Hope for empirical miracles}

One of the most intriguing but also baffling uses of modal concepts in Kant's Religion has to do with his occasional expressions of openness to the possibility of what might be called empirical miracles $(R 6: 52,84,88 \mathrm{n})$. He consistently rejects such miracles as authenticators of central religious doctrine, of course - no signs, wonders, or special revelations are required for us to understand what the moral law requires, or to understand the content of the moral proof. In Part Two, for instance, Kant asserts that we don't have either a theoretical or a practical need to postulate the virgin birth, and he also omits endorsement of the central Christian miracle - the bodily resurrection of Christ. In the general remark at the end of Part Two, he makes it clear that a moral religion ("the heart's disposition to observe all 
human duties as divine commands") is such that any miracles connected with its inception are utterly dispensable (6:83ff.). Indeed, it is a pernicious form of unbelief (Unglaube) to insist on miracles before (or instead of) accepting reason's practical dictates $(R 6: 63)$.

All the same, Kant is strikingly careful (for a determinist about the empirical world) not to rule out miracles altogether. He says repeatedly that "reason does not dispute the possibility or actuality" of historical miracles $(R 6: 52 ; \mathrm{cf} .88 \mathrm{n})$ and that it is "entirely conformable to the ordinary human way of thinking," for a new religion - even one based on "the spirit and the truth (on moral disposition)" - to announce or "adorn" its introduction with dazzling feats (R 6:84). Kant even claims to find it plausible that the work of a "prophet" or "founder" of a new religion would be full of miracles (thus helping to win adherents from the old religion), and that the historical testimony to these miracles itself would be miraculously arranged and preserved: "It may well be (es mag also sein)," he says without any obvious Humean insincerity, that Christ's "appearance on earth, as well as his translation from it, his eventful life and his passion, are all miracles indeed that the history that should testify to the account of these miracles is itself a miracle" ( $R$ 6:84-85).

Similar claims can be found in lectures on religion and metaphysics from the critical period. Kant clearly has Leibniz in mind when he insists, for instance, that

it is not at all impossible, even in the best world, that the powers of nature may sometimes require the immediate cooperation of God in order to bring about certain great ends. It is not impossible that the Lord of Nature might at times communicate to it a complementum ad sufficientiam in order to carry out his plan. ( $V p R$ 28:III2)

No world can be thought without deficiencies, without certain negations and limitations, and thus to make up the defect of nature, miracles are possible in the best world also, and even probable according to the concept of God's goodness and truth (MetM 29:871; see also Metaphysik - $K_{2}$ 28:732ff.).

A miracle strictly defined is called rigorous. [How] is such a thing possible? Because there is an extramundane cause that has produced this order of things, and thus can produce another. A miracle is thus possible in itself internally ... In general, an event in the world whose laws human reason cannot at all cognize is a miracle." (MD 28:667)

Such passages reveal at least an openness to the real possibility of anomalous empirical events. This coheres with the claim in the Religion that the rational person does not "dispute their possibility or actuality" even though 
she also does not "sanction (statuiert)" them for use in practical or theoretical reasoning (see $R$ 6:88 and note).

But what sort of possibility could Kant have in mind here? How could a miracle fit into his deterministic picture of the natural world? The texts are hardly clear about this, but one option that seems open to Kant is to adopt a variation on the Leibnizean approach to miracles, according to which there are two different sets or levels of "laws," only one of which is accessible to us. For Leibniz, empirical miracles are supposed to be possible, despite the validity of the Principle of Sufficient Reason (PSR), because the laws that we rely on in everyday life and seek to describe in natural science are merely the subordinate maxims of God's will - the policies according to which the best possible world normally operates. In certain circumstances, these policies may be suspended so that an event in the empirical world that is not in accordance with them occurs in accordance with higher purposes. Leibniz, devotee of orderliness and reason, cannot allow such events to be violations of the PSR, of course, and thus in the Discourse on Metaphysics (1686) and elsewhere, he claims that God has a hidden set of policies which are always in effect. These policies - which together constitute the so-called "law of the series" - entail the world's typical adherence to subordinate maxims but also allow for their occasional violation. The law of the series itself, however, is too complicated for finite minds to comprehend, and so we must aim, in scientific inquiry, to describe the intelligible if exceptionable subordinate maxims. ${ }^{16}$

A Kantian variation on this theme could make use of the distinction between empirical possibility and formal possibility discussed above. What usually occurs in the empirical world is determined by the laws that we rely on in common sense as well as scientific contexts. For all we know, however, these laws are suspended on occasion to allow an empirical miracle - i.e., "that which happens contrary to the order of nature in the world" - to occur (MetM 29:870). Such an event would still be formally possible in the sense that it would "agree" with the formal conditions of experience - the axioms of space and time, as well as the principles derived from the categories. And so there would still be a fundamental lawfulness, just as there is for Leibniz. But the event would be out of keeping with the more specific empirical laws

${ }^{16}$ Discourse on Metaphysics sections I6-I7 (I686), in Roger Ariew and D. Garber (eds.), Philosophical Essays (Indianapolis: Hackett Publishing Co., 1989), pp. 48-49. Elsewhere in this work it becomes clear that some events are not just above, but positively "contrary" to, the "subordinate maxims which we call the nature of things" (Discourse section 7, p. 40). He repeats this formulation in a letter to Arnauld of July I4, I686 - "miracles are contrary to some subordinate maxims or laws of nature" - in H. T. Mason (ed.), The Leibniz-Arnauld Correpondence (Manchester University Press, I967), p. 57, my emphasis. 
that typically describe what is actual and causally necessary. If this model is coherent, then it may be rational for a practitioner of Kantian religion to hope, in the right circumstances, for such an event to occur, even while assuming (for all practical and theoretical purposes) that it won't. The only claim about miracles that we must "dispute with all our might," Kant says, is that they authenticate a particular religion, or that belief in them is pleasing to God and/or religiously required ( $R$ 6:85).

There is more to be said about this, ${ }^{17}$ but since it is clear that empirical miracles are not a central focus of Kant's Religion, I propose to move on to two other uses of the concept of rational hope that go to the very heart of his theory.

\subsection{Hope for moral assistance}

The most prominent use of the concept of hope in Religion (as well as in Conflict of the Faculties and his lecture on religion) relates to the doctrine of "supernatural assistance" in the moral life. Kant says repeatedly that if we do our best to conform to the moral law, we can reasonably hope for supernatural assistance of some sort ( $R$ 6:48, 52-55, I71; $S$ 7:44; $V p R$ 28:1106). Sometimes it looks as though Kant takes the assistance to be ontological God actually plays a role in the conversion of our will. Other passages suggest that it is a question of perspective - God chooses to view our efforts at moral improvement as making us morally perfect, even though "in our earthly life (and perhaps even in all future times and in all worlds) [our moral state] is always only in mere becoming" ( $R$ 6:75).

There are notorious problems with both of these suggestions from the point of view of Kantian ethics. The latter, "two perspectives" approach ascribes to God an odd sort of overestimation or self-deception: even though finite agents are not wholly good and perhaps never will be, those who are making progress somehow "appear justified before their judge" ( $R$ 6:74) or are "judged by him who scrutinizes the heart (through his pure intellectual intuition) to be a perfected whole" ( $R$ 6:67). There is more to say about this approach, ${ }^{\mathrm{I}}$ but here I want to focus on the former one - the one

17 See Andrew Chignell, "Rationalism, Religion, and the Laws: Leibniz and Kant on Miracles," in Brandon Look (ed.), Leibniz and Kant (New York: Oxford University Press, 20I4). For alternative approaches to the topic, see A. Tuan Nuyen, "Kant on Miracles," History of Philosophy Quarterly 19 (2002), pp. 309-23, and chapter 7 by Karl Ameriks in the present volume.

I8 See Gordon E. Michalson, Jr.'s negative review of the "perspectives" account in his Fallen Freedom: Kant on Radical Evil and Moral Regeneration (Cambridge University Press, 1990), pp. I03ff. See Stephen R. Palmquist, Kant's Critical Religion (Aldershot and Burlington: Ashgate, 200o), and Christopher McCammon, "Overcoming Deism," for more positive assessments. 
according to which God is ontologically involved. This is the approach that Kant often seems to favor, but it is deeply problematic insofar as it seems to undermine his commitment to human autonomy. We can see this in the following argument:

(PI) If $S$ is morally responsible for changing the quality of his will, then $S$ is fully ontologically responsible ${ }^{19}$ for changing the quality of his will.

(P2) S is not fully ontologically responsible for changing the quality of his will.

(C) Thus, $S$ is not morally responsible for changing the quality of his will.

The conclusion is obviously anathema for Kant, and so something's got to give. (PI), however, is just a statement of what is often called Kant's "Stoic maxim":

The human being must make or have made himself into whatever he is or should become in a moral sense, good or evil. ( $R$ 6:44, emphasis Kant's)

For he ought to become a good human being yet cannot be judged morally good except on the basis of what can be imputed to him as done by him. (R 6:5I, emphasis Kant's) ${ }^{20}$

(PI) thus seems unassailable. Given his theory of autonomy generally, however, it seems clear that Kant will have to reject $\left(\mathrm{P}_{2}\right)$ : a moral subject is fully ontologically responsible - is the sufficient ground - of her own moral character. But then what room is left for supersensible assistance?

The problem here is sometimes referred to as the "conundrum" in Kant's theory of moral improvement. ${ }^{2 I}$ Here it is formulated as an allegedly inconsistent quartet:

I9 "Cause/effect" is a pure category of the understanding, and has genuine application only with respect to phenomenal states and objects. There is an "unschematized" form of that concept, however, that can be used to "think" about noumenal things: Kant calls it "ground and consequence." A ground-consequence relation can be posited between abstract entities such as premises in a proof, for instance, but it can also be thought (if not known) to hold between things-in-themselves (see $\mathrm{A}_{73} /$ B98, A243ff./B3orff.). In order to avoid confusing talk of "causation" in this context, I'll refer to the grounding relation as one of "ontological responsibility."

20 Nicholas Wolterstorff is the source of the phrase "Stoic maxim": Wolterstorff, "Conundrums in Kant's Rational Religion,” in Philip J. Rossi and Michael Wreen (eds.), Kant's Philosophy of Religion Reconsidered (Bloomington/Indianapolis: Indiana University Press, I99I), pp. 40-53. See also John Hare, The Moral Gap: Kantian Ethics, Human Limits, and God's Assistance (New York: Oxford University Press, 1996).

${ }^{21}$ See, e.g., Michalson, Fallen Freedom; Wolterstorff, "Conundrums"; and Chris L Firestone and Nathan Jacobs, In Defense of Kant's Religion (Bloomington/Indianapolis: Indiana University Press, 2008). 
(A) $\mathrm{S}$ is morally responsible for making himself good (i.e. for changing the quality of his will from evil to good) (from Kant's ethics)

(B) $\mathrm{S}$ can make himself good (from [A] and Ought-Implies-Can)

(C) If $S$ is morally responsible for making himself good, and $S$ can make himself good, then $S$ is fully ontologically responsible for making himself good as well (Stoic maxim)

(D) $S$ requires God's assistance in becoming good (from $[\mathrm{A}]-[\mathrm{C}]$ )

The conundrum here arises from the fact that the conjunction of any three is supposed to be incompatible with the fourth. But Kant cannot reject (A), given his overall ethical theory, and he cannot retain (A) and reject (B) without violating Ought-Implies-Can (which is clearly endorsed in Religion at $R$ 6:45 and 62). So, say the conundrumists, he is forced to deny either (C) - the Stoic maxim - or (D) the requirement of divine assistance, both of which he seems to endorse.

I want to suggest, in contrast, that once we clarify the kind of modality at work in this context, the incompatibility, and the conundrum, disappear. For even if (A)-(C) are true, it might still be in some sense possible (and thus possibly required) for $S$ to receive some sort of assistance. The possibility would not be empirical, of course, since we're talking about non-empirical states of the will. But there are at least two other options. First, consider the noumenal analogue of empirical possibility. There are presumably principles analogous to "laws" in the intelligible world of free agents, and so perhaps these laws allow two different agents to be fully ontologically responsible for the same action. The picture would thus be similar to scholastic and early modern doctrines of concurrence, though at the merely intelligible rather than empirical level. It is revealing in this regard, then, that in his lectures Kant explicitly refers to the doctrine of supersensible assistance as involving a concursus divinus ( $V p R$ 28:IIO6) or even a concursum morale ( $V p R$ 28:IIIO).

Conundrum theorists will insist here, however, that this is just obviously a violation of Kant's strongly held doctrines about libertarian freedom. And, to be sure, elsewhere in his arguments about freedom, Kant does seem to indicate that a free act is an "unconditioned" event, one that cannot involve the assistance of another agent without violating the "laws" of freedom.

The second option simply grasps this nettle. Perhaps such a violation is precisely what Kant has in mind when he talks about supersensible assistance: it is a violation of the "laws" of the intelligible world of free agents, and yet it is possible in some deeper sense, and can thus still be the object of rational hope. Here is more of the passage just cited from the religion lectures: 
Of course this idea of freedom is one which belongs to the intelligible world, and we are acquainted with nothing of it beyond the fact that it exists, so we also do not know the laws by which it is governed. But even if our reason cannot deny the possibility of this concursus, it still sees that such an effect would have to be a miracle of the moral world, just as God's acts of cooperation with occurrences in the sensible world are God's miracles in the physical world. ${ }^{22}$ ( $V p R$ 28:IIO6-7)

Kant draws an important analogy at the end of this passage: just as an empirical miracle is possible even though it violates the particular laws of the empirical world, he suggests, perhaps a moral concursus is possible at some absolutely fundamental level, even though it violates the "laws" of the intelligible world.

We find complementary passages in Religion in which Kant suggests both that our moral state is "incumbent" on us, and yet that assistance may be possible. In the first of these, he also makes the same analogy between the natural scientist's ignorance (given his "occupation" of investigation) of the deep grounds of nature's patterns, and the moral agent's ignorance of whether he's receiving some supersensible aid:

Now, to occupational affairs (Geschäften) also belongs the natural scientist's search for the causes of events in the natural laws governing those events; I mean the natural laws of those events that he can thus verify through experience, even though he must renounce acquaintance (Kenntnis) of that, in itself, which brings about effects according to these laws, or of what these laws for us might be relative to some other possible sense-faculty. A human being's moral improvement is likewise an occupational affair (Geschäfte) incumbent upon him, and heavenly influences may indeed always cooperate in this improvement, or be deemed necessary to explain its possibility. Yet he himself has no understanding in the matter: neither how to distinguish with certainty such influences from the natural ones, nor how to bring them and thus, as it were, heaven itself down to himself; thus, since he doesn't know what to do with them, he does not in this case sanction miracles but rather, if he pays heed to the call of reason, conducts himself as if all change of heart and improvement rests solely on the application of his own effort. ${ }^{23}(R$ 6:87-88)

${ }^{22}$ In the practical works, Kant often uses the phrase "laws of freedom" or "laws of the intelligible world" to refer to the moral law (e.g. G 4:453-54). But in this passage he must be speaking of the "laws" that govern the intelligible domain of freedom in some broader sense, since he says that we don't know them, and we do of course know the moral law. Compare, here, a passage in Religion where Kant indicates that what we are acquainted with in practical cognition is only a subset of these laws, namely the moral ones: "But we are at least acquainted with the (moral) laws of freedom" (R 6:I9I, Kant's parenthesis and emphasis).

${ }^{23}$ Kant attaches a key footnote to the word "sanction" (statuirert) here, part of which I quoted earlier: "This is the same as saying that he does not incorporate miracles into his maxims (either of theoretical or practical reason), even though he does not dispute (anfechten) their possibility or actuality." 
Reason says that whoever does, in a disposition of true devotion to duty, as much as lies within his power to satisfy his obligation (at least in a steady approximation toward complete conformity to the law), can legitimately hope (hoffen dürfe) that what lies outside his power will be supplemented by the supreme wisdom in some way or other (which can render permanent the disposition to the steady approximation), without reason thereby presuming to determine that way or to know (wissen) what it consists in, for God's way can perhaps be so mysterious that, at best, he could reveal it to us in a symbolic representation in which the practical import alone is comprehensible to us, whereas, theoretically, we could not in the least grasp what this relation of God to the human being is in itself, or attach concepts to it, even if God wanted to reveal such a mystery to us. (R 6:I7I)

To Believe that grace may have its effects, and that perhaps there must be such effects to supplement the imperfection of our striving for virtue, is all that we can say on the subject. ( $R$ 6:174, my emphasis)

This is precarious territory for a critical philosopher, as Kant himself recognizes. In both the lectures and Religion, he frequently falls back to the weaker point that we can't presume to know that assistance is impossible: "as regards a concursum morale or God's free cooperation in the free actions of human beings, such a thing cannot be comprehended in the nature of freedom" but "at the same time it cannot be regarded as impossible" ( $V p R$ 28:IIIO).

The concept of a supernatural intervention into our moral though deficient faculty ... this is a transcendent concept, merely in the idea of whose reality no experience can assure us ... Yet its impossibility (that the two may not occur side by side) cannot be proven either, since freedom itself, though not containing anything supernatural in its concept, remains just as incomprehensible to us according to its possibility as the supernatural [assistance] we might want to assume as surrogate for the independent yet deficient determination of freedom. (R 6:19I)

This kind of disavowal of modal knowledge follows from Kant's general commitment to ignorance about absolute real possibility. But does denying knowledge here leave room for rational modal Belief?

I want to suggest that it does. Kant clearly thinks there has to be room for hope here, and as we have seen, his condition on rational hope (RHKant) requires more than mere suspension of judgment about the modal issue. One needs at least the positive Belief, on sufficient practical grounds, that a "miracle of the moral world" is really possible. The two proposals I've sketched above attempt to make sense of how this might work. If the incompatibility between assistance and autonomy can be regarded as merely apparent, or if it can be regarded as a genuine incompatibility at the 
derivative level of "laws" rather than the most fundamental modal level, then Belief in the real possibility of assistance (as well as "moral hope" for it) would be able to withstand rational scrutiny, even if all claims to modal knowledge must be denied. ${ }^{24}$

\subsection{Hope for social progress}

One of the other main controversies in the current literature on Kant's theory of evil has to do with how our position in society relates to our morally evil acts - is it necessary for moral evil, or sufficient, or neither, that we be in community with others? ${ }^{25}$ Whatever the right answer, it is clear that Kant views communal life as morally precarious: "As soon as he is among human beings," a man almost inevitably falls into the kind of "envy, addiction to power, avarice, and the malignant inclinations associated with these" that wouldn't afflict a lonesome Crusoe on his separate island $(R$ 6:93-94). Kant's catch-phrase for this thesis is "unsocial sociability"; it plays a prominent role in his Idea for a Universal History (1784), and has predecessors in the writings of Montaigne and Rousseau.

Given that isolation is impractical and that we have a propensity to competitive nastiness and "mutual corruption," Kant says, we can only rationally "hope for a victory of the good principle over the evil one" through the "setting up and diffusion of a society in accordance with, and for the sake of, the laws of virtues" ( $R$ 6:94). This is not a political state but rather an "ethical community" formed for moral reasons, and its possibility is what grounds rational hope for the ultimate victory of good over evil both individual and collective.

But what precisely are we willing when we will to form an ethical community? Kant says in Religion that the ethical community is "universal" by way of involving the entire human race; later he calls it the "invisible" albeit "true church," and says it has the "modality" of being "unchangeable." So, while the ethical state of nature leaves us with "public feuding between virtue and inner immorality" ( $R$ 6:97), the ethical community will be an as-yet-unseen social arrangement that results in universal harmony and mutual moral encouragement.

${ }^{24}$ For a longer and more detailed exposition of this argument, see Chignell, "Rational Hope, Moral Order, and the Revolution of the Will," in Eric Watkins (ed.), Divine Order, Human Order, and the Order of Nature (New York: Oxford University Press, 2013) pp. 198-2I8.

${ }^{25}$ For recent discussions of this debate, see Jeanine Grenberg, "Social Dimensions of Kant's Conception of Radical Evil," in Sharon Anderson-Gold and Pablo Muchnik (eds.), Kant's Anatomy of Evil (Cambridge University Press, 20I0), pp. 173-94; and Allen W. Wood, "Kant and the Intelligibility of Evil," in Anderson-Gold and Muchnik (eds.), Kant's Anatomy of Evil, pp. 144-72. 
Given that we ought to will such a community and that ought-impliescan, the community must be really possible. But an individual cannot generate it on his own, and he cannot assume or even hope that others will play along: the "objective reality" of the idea of an ethical state (and thus its real possibility), Kant says, is "entirely well-grounded" in "human reason (in the duty to join such a state), even though we cannot subjectively ever hope of the good will of human beings that these will work harmoniously toward this end" ( $R$ 6:95).

More strikingly, even if all of us were to will the collective good, Kant still thinks that this would not guarantee the possibility of its achievement. This is because the "ethical community" (like the "moral world" discussed earlier) has an empirical component, and the inscrutable gulf between intelligible freedom and empirical nature leaves it unclear whether or how it can be brought about: "we cannot know whether as a whole it is also in our power" ( $R$ 6:98). Thus a commitment to the real possibility of the ethical community that we are obliged to construct must be grounded in "a higher moral being through whose universal organization the forces of single individuals, insufficient on their own, are united for a common effect" ( $R$ 6:98).

What we encounter in the discussion of our social duties in Religion, then, is effectively another practical proof. We can't know that an ethical community is really possible, but once we see that we ought to will it, we have to Believe on practical grounds that it is indeed possible. This in turn licenses Belief in supersensible assistance, and also underwrites rational hope for a this-worldly but still inconceivable goal. ${ }^{26}$

Despite this sort of appeal to providence in both the Religion and the various critical discussions of human history (especially the third Critique), Kant is careful to insist that one must not wait for an intervention, or passively assume that someone else is in control. Each person must act "as if everything depended on him. Only on this condition may he hope that a higher wisdom will provide the fulfillment of his well-intentioned effort" ( $R$ 6:IoI, my emphasis). This is an explicit effort to avoid what he regards as the morally enervating aspects of stronger, more Calvinist doctrines of providence. Still, Kant is clear that once we have recognized our ethical

26 O’Neil, "Kant on Reason and Religion," goes over some of this same material in an effort to find an account of "hope without doctrine" (p. 280). If we can manage to keep the focus entirely on thisworldly progress, she says, perhaps we can take Kant's argument to underwrite the Belief that the ethical community is possible and the hope for its achievement as a result of our efforts alone, without an appeal to providence. See Flikschuh, "Hope as Prudence," for a critical assessment of O'Neill's view here. 
duty in society and conformed our will to it, we are implicitly committed to Belief that its achievement in a this-worldly context is really possible, and able to have rational hope for this "fulfillment."

\section{Conclusion: hope in place of belief}

The importance of the difference between knowledge and rational Belief (Vernunftglaube) in Kant is clear - we have to set aside the former in order to make room for the latter (Bxxx). Less widely recognized, however, is the fact that hope differs from both of these - in its structure, scope, and rationality conditions. Once we understand Kant's conception of rational hope, we can (I submit) make better sense of the intriguing - if perennially baffling - references to empirical, moral, and social "miracles" in Religion and related writings. In other words, given the availability of rational hope, the "bounds of mere reason" within which Kantian religion is contained may turn out to be quite a bit wider than the bounds of either knowledge or rational Belief. 